\title{
Regulation of N-Acetylkanamycin Amidohydrolase in the Idiophase in Kanamycin Fermentation
}

\author{
Atsuyuki Satoh, Hiroshi Ogawa and Yukio Satomura* \\ Pharmaceutical Development Laboratories, Meiji Seika Kaisha, Ltd., Kawasaki, Japan \\ *Faculty of Science, Osaka City University, Osaka, Japan \\ Received August 8, 1975
}

\begin{abstract}
Formation of N-acetylkanamycin amidohydrolase (NAKA) in a strain of Streptomyces kanamyceticus proceeded in parallel with the increase of both kanamycin (KM) and N-acetylkanamycin (NAK) in the initial period. NAKA formation then suddenly began to decrease in NAK but KM continued to increase before reaching a maximum level. The study on conversion of intracellular NAK into KM using washed cells has shown that the endogenous activity of NAKA is most efficiently induced by acetate together with the activity of isocitrate lyase and N-acetyltyrosine amidohydrolase. Sclerin (SCL) stimulated their induction in the same manner, while N-acetyltyrosine repressed NAKA. Glucose effect was relieved by SCL and some amino acids. From these results, change in the chemical composition of cells in idiophase was well elucidated.
\end{abstract}

It has been shown previously that the activity of KM acetyltransferase (KAT) essential in KM biosynthesis in the strain of S. kanamyceticus is associated with citrate lyase. $\left.{ }^{1,5}\right)$ Citrate lyase, an anaplerotic enzyme, produces acetate and oxalacetate from citrate, and the acetate must be used by KAT for acetylation of KM-composing aminoglycoside. Oxalacetate inhibits the KAT reaction, as reported previously. ${ }^{1)}$ Accumulation of acetyl $\sim \mathrm{CoA}$ then stimulates phosphoenolpyruvate (PEP) carboxylase, ${ }^{2 \sim 4)}$ elevating the concentration of oxalacetate. A high concentration of oxalacetate favors the carbohydrate synthesis in the amphibolic pathway. Thus, the formation of NAK, a precursor of KM, may be preceded by synthesis of a carbohydrate component in cells of trophophase. Conversely, the accumulation of NAK in the cells at idiophase stimulates aerobic decomposition of the carbohydrate removing the inhibition by acetyl $\sim$ CoA on pyruvate dehydrogenase. ${ }^{2 \sim 4)}$ On the other hand, the function of NAKA in the idiophase might restore the gluconeogenesis from the acetate by liberating the acetate group from NAK. It is supposed that NAKA participates in the anaplerotic pathway in carbohydrate metabolism. In the present paper, the effect of carbon-sources and SCL on the regulation of NAKA in idiophase was investigated using a washed-cell system. Changes in the chemical composition of cells during KM fermentation were also examined.

\section{MATERIALS AND METHODS}

Strain and culture condition. These were the same as in previous papers, ${ }^{1,5}$ using $S$. kanamyceticus K. 133-28.

Preparation and incubation of washed-cell suspensions. About $1 \mathrm{~g}$ (moist weight) of cells grown for $48 \sim 72 \mathrm{hr}$ was centrifuged, washing twice with $0.1 \mathrm{M}$ Tris- $\mathrm{HCl}$ buffer (pH 8.5), suspended in $10 \mathrm{ml}$ of $0.1 \mathrm{M}$ Tris- $\mathrm{HCl}$ buffer (pH 8.5) in $100 \mathrm{ml}$ Erlenmeyer flask, and incubated at $28^{\circ} \mathrm{C}$ for $24 \mathrm{hr}$ with shaking.

Determination of $K M$ and $N A K$ (endogenous activity of $N A K A$ ). Production of KM in growing cells was measured as previously reported. ${ }^{5)}$ Conversion of intracellular NAK into KM in washed-cell suspensions was determined as follows: Cell suspensions were disrupted by ultrasonication $(10 \mathrm{kc} / \mathrm{sec}$ for $5 \mathrm{~min}$ ) at $3^{\circ} \mathrm{C}$, adjusted at $\mathrm{pH} 2.0$, centrifuged and neutralized with $\mathrm{NaOH}$ (free-KM). Then, the supernatant was hydrolyzed by $2 \mathrm{~N} \mathrm{NaOH}$ at $100^{\circ} \mathrm{C}$ for $60 \mathrm{~min}$ and neutralized (total KM after alkali hydrolysis). KM potency in each neutralized solution was determined as previously reported ${ }^{1,5)}$ NAK was calculated as total KM minus free-KM. Endogenous activity of NAKA 
expressed as the conversion rate $(\%)$ of intracellular NAK into KM.

Activity of NAKA in cell-free extracts. The cells were collected by centrifugation at $3000 \times g$ for $10 \mathrm{~min}$, washed twice with $0.1 \mathrm{M}$ Tris-HCl buffer $(\mathrm{pH} \mathrm{8.0)}$, disrupted by a motor grinder with powdered glass, suspended in the same buffer and centrifuged at $30,000 \times g$ for $30 \mathrm{~min}$. The supernatant was dialyzed against $0.1 \mathrm{M}$ Tris- $\mathrm{HCl}$ buffer ( $\mathrm{pH} 8.0$ ) at $5^{\circ} \mathrm{C}$ for $24 \mathrm{hr}$ and used as the enzyme solution. A reaction mixture containing enzyme solution $(4 \sim 5 \mathrm{mg}$ protein $/ \mathrm{ml})$ and $0.1 \mathrm{~mm}$ NAK in $10 \mathrm{ml}$ of $0.1 \mathrm{M}$ Tris- $\mathrm{HCl}$ buffer ( $\mathrm{pH} 8.0$ ) was incubated at $28^{\circ} \mathrm{C}$ for $180 \mathrm{~min}$. After incubation, the amount of KM formed was determined as previously reported. ${ }^{1,5}$ One unit (u) of the enzyme activity was expressed as, $\mu$ moles of $\mathrm{KM}$ liberated/100 $\mathrm{mg}$ dry cells/60 $\mathrm{min}$.

Activity of $N$-acetyltyrosine amidohydrolase and isocitrate lyase. $\mathrm{N}$-Acetyltyrosine amidohydrolase was measured by intact cells. A reaction mixture containing $1 \mathrm{~g}$ cells and $1 \mathrm{~mm} \mathrm{~N}$-acetyltyrosine in $10 \mathrm{ml}$ of $0.01 \mathrm{M}$ phosphate buffer ( $\mathrm{pH} 8.5$ ) was incubated at $28^{\circ} \mathrm{C}$ for 60 min with shaking. After incubation, the amount of tyrosine liberated was determined by the Ninhydrin method, ${ }^{61}$ and $1 \mathrm{u}$ of the enzyme activity was expressed as $\mathrm{mg}$ tyrosine released $/ 100 \mathrm{mg}$ dry cells/60 min. Isocitrate lyase was measured according to the method described by Daron and Ganalus, ${ }^{7 !}$ by preparing a cellfree extracts similar to that described above but using a $0.1 \mathrm{M}$ Tris- $\mathrm{HCl}$ buffer ( $\mathrm{pH} 7.9$ ) containing $0.005 \mathrm{M}$ dithiothreitol. One unit (u) of the enzyme activity was expressed as $\mu$ moles of glyoxylate formed/100 $\mathrm{mg}$ dry cells/10 min.

Analysis of cell components. The contents of lipid, protein and carbohydrate in the cells were analyzed by the method of Schmidt-Thanhauser-Schneider. ${ }^{8 \sim 10}$ Moreover, the carbohydrate content was checked by other methods, ${ }^{11-143}$ and shown to contain approximately $60 \sim 95 \%$ sugars determined as glucose or glucosamine after hydrolysis. Total- $\mathrm{N}$ was determined by the method of Kjeldahl. ${ }^{15}$,

\section{RESULTS}

\section{Formation of NAKA during KM fermentation} and conversion of intracellular NAK into KM As presented in Fig. 1, the activity of NAKA in $S$. kanamyceticus cell-free extracts during KM fermentation appeared just at $48 \mathrm{hr}$ and increased for a while in parallel with the production of KM and NAK. The activity suddenly began to decrease NAK at $72 \mathrm{hr}$ and gradually declined after attaining a peak at
$96 \mathrm{hr}$. The production of KM increased linearly until the end. If the production of NAK did not occur after $72 \mathrm{hr}$, the linear increase of $\mathrm{KM}$ in the latter half of idiophase must depend on stimulation of the endogenous activity of NAKA.

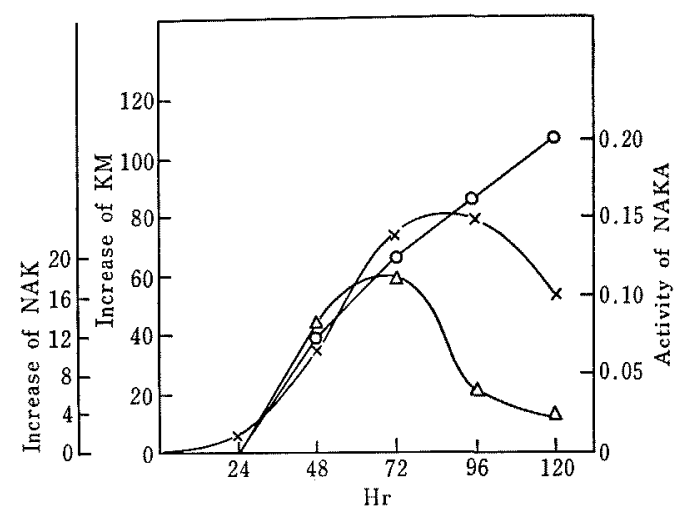

FIg. 1. Time Course of the Formation of NAKA and Increase of NAK and KM in S. kanamyceticus during KM Fermentation.

$\bigcirc-\mathrm{O}, \mathrm{KM}, \mu \mathrm{g} / \mathrm{mg}$ dry cells; $\triangle-\triangle, \mathrm{NAK}, \mu \mathrm{g} / \mathrm{mg}$ dry cells; $\times-\times$, activity of cell-free extracts, $10 \times u$ / $100 \mathrm{mg}$ dry cells.

SCL has previously been found to stimulate the formation of KM and NAKA. ${ }^{53}$ The effect of SCL on conversion of intracellular NAK into $\mathrm{KM}$ in washed-cell suspensions was examined. As shown in Table I, when growing cells were harvested at $48 \mathrm{hr}$ for preparing the

Table I. EfFect of SCL on Conversion of INTRACELLULAR NAK INTO KM IN WASHED-CELL SUSPENSIONS DURING INCUBATION FOR $24 \mathrm{HR}$

\begin{tabular}{|c|c|c|c|c|c|}
\hline \multirow{2}{*}{$\begin{array}{l}\text { Age } \\
\text { of cells } \\
\text { hr }\end{array}$} & \multirow{2}{*}{$\begin{array}{l}\left.\mathrm{SCL}^{a}\right) \\
\text { ppm }\end{array}$} & \multicolumn{2}{|c|}{$\begin{array}{l}\mathrm{NAK} \\
\mu \mathrm{g} / \mathrm{ml}\end{array}$} & \multirow{2}{*}{$\begin{array}{c}\mathrm{KM} \\
\text { formed } \\
\mu \mathrm{g} / \mathrm{ml}\end{array}$} & \multirow{2}{*}{$\begin{array}{l}\text { Conver- } \\
\text { sion } \bar{b} \\
\text { rate } \%\end{array}$} \\
\hline & & Initial & maining & & \\
\hline 48 & 0 & 82 & 90 & 13 & 16 \\
\hline 48 & $5^{(1)}$ & 82 & 100 & 17 & 21 \\
\hline 72 & 0 & 117 & 50 & 62 & 53 \\
\hline 72 & 5 & 117 & 30 & 90 & 78 \\
\hline
\end{tabular}

a) SCL was added in $0.1 \mathrm{M}$ Tris- $\mathrm{HCl}$ buffer (pH8.5) containing $0.5 \%$ glucose and $0.01 \mathrm{M} \mathrm{MgSO}_{4}$.

b) $\mathrm{KM}$ formed/NAK initial $\times 100$.

b) $5 \mathrm{ppm}=2.1 \times 10^{-5} \mathrm{M}$. Washed-cell suspensions were prepared and incubated as described in MATERIALS AND METHODS. 
washed cells, intracellular NAK increased during incubation for $24 \mathrm{hr}$, and its conversion rate into $\mathrm{KM}$ was very low. At this period SCL had only a slight effect. With cells grown for $72 \mathrm{hr}$, SCL markedly stimulated the conversion of NAK into KM. The effect of SCL may have a close relationship to the metabolic pattern or the structure of cells in the transition period from trophophase to idiophase. As shown in Table II, when cells were pre-

Table II. Effect of Pretreatment of Cells on ENDogenous Activity of NAKA

\begin{tabular}{lc}
\hline Pretreatment & $\begin{array}{c}\text { Endogenous activity } \\
\text { of NAKA }\end{array}$ \\
\hline Control & 16 \\
Freeze-drying $^{b 1}$ & 32 \\
Acetone $^{b)}$ & 61 \\
Toluol $^{c 1}$ & 100 \\
\hline
\end{tabular}

a) Conversion rate $(\%)$ of intracellular NAK into $\mathrm{KM}$ was computed by the same formula as in Table I.

b) Dried cells at $70 \mathrm{mg}$ corresponding to $1 \mathrm{~g}$ moist weight were used.

c) Washed cells were stirred for $1 \mathrm{hr}$ in $0.01 \mathrm{M}$ phosphate buffer containing $2 \%$ toluol and filtrated. After treatment, $1 \mathrm{~g}$ of moist cells was collected and used.

Age of cells used was $48 \mathrm{hr}$.

treated by toluol, intracellular NAK was completely converted by NAKA into KM under the same conditions as described above. Pretreatment of cells by acetone or freezedrying also stimulated the endogenous activity of NAKA to some extent.

Effect of sugars and SCL on endogenous activity of NAKA

As shown in Table III, when washed cells were incubated with a high concentration $(1 \%)$ of sugars such as glucose, fructose, mannose, maltose and lactose, the endogenous activity of NAKA was markedly repressed while sucrose and gluconate had no repressive effect. Raffinose and starch had a rather stimulating effect. As shown in Table IV, the repression of NAKA by glucose was reversed by SCL and some amino acids, such as aspartic and glutamic acids. Though cyclic AMP
Table III. Effect of Sugars on Endogenous ACTIVITY OF NAKA

\begin{tabular}{|c|c|c|c|}
\hline $\begin{array}{l}\text { Sugars } \\
\text { at } 1 \%\end{array}$ & \multicolumn{3}{|c|}{$\begin{array}{l}\text { Endogenous activity } \\
\text { of NAKA }\end{array}$} \\
\hline Glucose & \multicolumn{3}{|c|}{18} \\
\hline Fructose & \multicolumn{3}{|c|}{2} \\
\hline Mannose & \multicolumn{3}{|c|}{25} \\
\hline Galactose & \multicolumn{3}{|c|}{42} \\
\hline Lactose & \multicolumn{3}{|c|}{0} \\
\hline Maltose & \multicolumn{3}{|c|}{30} \\
\hline Sucrose & \multicolumn{3}{|c|}{57} \\
\hline Raffinose & \multicolumn{3}{|c|}{82} \\
\hline Starch & \multicolumn{3}{|c|}{62} \\
\hline Gluconate & \multicolumn{3}{|c|}{57} \\
\hline Control (glucose $0.5 \%$ & \multicolumn{3}{|c|}{53} \\
\hline \multicolumn{4}{|c|}{$\begin{array}{l}\text { a) Method of computation is same as Table II for } \\
\text { detail see MATERIALS AND METHODS. }\end{array}$} \\
\hline \multicolumn{4}{|c|}{ 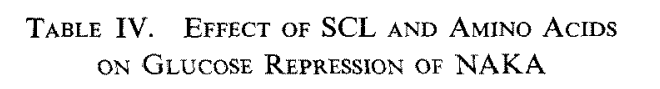 } \\
\hline \multirow[t]{2}{*}{ Addition } & \multicolumn{3}{|c|}{$\begin{array}{l}\text { Endogenous activity }{ }^{a /} \text { of } \\
\text { NAKA } \\
\text { at glucose concentration }(\%)\end{array}$} \\
\hline & 0.5 & 1.0 & 2.0 \\
\hline None & 53 & 18 & 12 \\
\hline $\operatorname{SCL}\left(2 \times 10^{-5} \mathrm{M}\right)$ & 78 & 49 & 45 \\
\hline $\mathrm{SCL}\left(4 \times 10^{-5} \mathrm{M}\right)$ & 53 & 40 & 32 \\
\hline c-AMP $\left(0.9 \times 10^{-5} \mathrm{M}\right)$ & 50 & 50 & 45 \\
\hline Asp $(0.1 \%)$ & 55 & 70 & 25 \\
\hline Glu $(0.1 \%)$ & 65 & 65 & 25 \\
\hline Asp $+\mathrm{SCL}\left(4 \times 10^{-5} \mathrm{M}\right)$ & - & - & 85 \\
\hline Glu + SCL $\left(4 \times 10^{-5} \mathrm{M}\right)$ & - & - & 60 \\
\hline
\end{tabular}

a) The same as in Table III.

abolished the glucose effect, it had no stimulatory effect on NAKA at a low glucose concentration.

Effect of acetate on endogenous activity of $N A K A$ and the activity of isocitrate lyase and $N$-acetyltyrosine amidohydrolase

As shown in Table $\mathrm{V}$, among carbon sources other than sugars, acetate specifically stimulated the endogenous activity of NAKA at a low concentration. Also, as shown in Table VI, acetate induced the activity of isocitrate lyase and $\mathrm{N}$-acetyltyrosine amidohydrolase in the washed-cell suspensions. Moreover, as shown in Table VII, SCL stimulated the activity of both isocitrate lyase and $\mathrm{N}$-acetyl- 
Table V. Effect of Acetate, Ethanol and OXAlaceTate on ENDOGENOUS ACTIVITY OF NAKA

\begin{tabular}{lc}
$\begin{array}{c}\text { Addition } \\
\text { at } 5 \text { ppm }\end{array}$ & $\begin{array}{c}\text { Endogenous activity } \\
\text { of }\end{array}$ \\
None & 42 \\
Acetate & 81 \\
Ethanol & 64 \\
Oxalacetate & 51 \\
\hline
\end{tabular}

a) The same as in Table III.

Table VI. Effect of Acetate on Induction OF IsOcitrate LyaSE AND N-ACETYLTYROSINE AMIDOHYDROLASE IN WASHED-Cell SUSPENSIONS

Washed-cell suspensions were incubated for $24 \mathrm{hr}$ as described in the text.

\begin{tabular}{lcc}
\hline Acetate & $\begin{array}{c}\text { Isocitrate } \\
\text { lyase }\end{array}$ & $\begin{array}{c}\text { Activity of } \\
\text { N-Acetyltyrosine } \\
\text { amidohydrolase }^{b}\end{array}$ \\
\hline 0 & 0.69 & 0.95 \\
2.5 & 0.89 & - \\
5.0 & 1.02 & 1.90 \\
\hline a) $\mathrm{u} / 100 \mathrm{mg}$ dry cells $/ 10 \mathrm{~min}$ (Age of cells was $72 \mathrm{hr}$ ). \\
b) $\mathrm{u} / 100 \mathrm{mg}$ dry cells $/ 60 \mathrm{~min}$.
\end{tabular}

TAble VII. EFFect of SCL ON THE Activity OF ISOCITRATE LYASE AND N-ACETYLTYROSINE AMTDOHYDROLASE

\begin{tabular}{ccc}
\hline $\begin{array}{c}\text { SCL } \\
\text { ppm }\end{array}$ & $\begin{array}{c}\text { Activity }{ }^{(a)} \text { of } \\
\text { Isocitrate } \\
\text { lyase }\end{array}$ & $\begin{array}{c}\text { N-Acetyltyrosine } \\
\text { amidohydrolase }\end{array}$ \\
\hline 0 & 1.15 & 1.06 \\
0.1 & 1.48 & 1.96 \\
1.0 & 1.89 & 1.97 \\
10.0 & 1.56 & 1.99 \\
\hline
\end{tabular}

a) The activity was calculated in the same manner as in Table VI, but age of cells used was $96 \mathrm{hr}$. tyrosine amidohydrolase. With the latter enzyme activity, there was a question on identity with NAKA. As shown in Table VIII, the

TABle VIII. EFFEct OF N-Acetyltyrosine on Endogenous ACTIVITY of NAKA

\begin{tabular}{ccc}
\hline $\begin{array}{c}\text { N-Acetyltyrosine } \\
\text { mM }\end{array}$ & $\begin{array}{c}\text { Activity }^{b /} \text { of } \\
\text { N-Acetyltyrosine } \\
\text { amidohydrolase }\end{array}$ & NAKA \\
\hline 0 & 1.02 & 56 \\
0.1 & 0.95 & 14 \\
1.0 & 0.95 & 10 \\
10.0 & 1.00 & 6
\end{tabular}

a) N-Acetyltyrosine was added to $0.01 \mathrm{M}$ phosphate buffer (pH 8.5) containing $0.5 \%$ glucose and $0.01 \mathrm{M} \mathrm{MgSO}_{4}$.

b) Calculated by same method as in Tables III and VI.

addition of $\mathrm{N}$-acetyltyrosine markedly repressed the endogenous activity of NAKA in the washed-cell suspensions. This indicates the presence of $\mathrm{N}$-acetylamino acid amidohydrolase other than NAKA in the cells.

Changes in the chemical composition of cells and isocitrate lyase level during KM fermentation

Changes in the chemical composition of cells during $\mathrm{KM}$ fermentation were investigated to examine the role of isocitrate lyase in the cells. As shown in Table IX, among several cell components, carbohydrate exhibited a characteristic change, and the change was prominent especially with cells grown in the presence of SCL. The carbohydrate content of cells in trophophase increased rapidly within

Table IX. Changes in the Chemical Composition of Cells during KM Fermentation WITH OR WITHOUT ADDITION OF SCL

\begin{tabular}{|c|c|c|c|c|c|c|c|c|}
\hline \multirow{2}{*}{$\begin{array}{c}\mathrm{Age}^{a)} \\
\text { of cells } \\
\text { hr }\end{array}$} & \multicolumn{4}{|c|}{ None } & \multicolumn{4}{|c|}{ SCL (5 ppm) } \\
\hline & Lipid & Carbohydrate & Protein & Total-N & Lipid & Carbohydrate & Protein & Total-N \\
\hline 24 & 16.6 & 26.4 & 24.8 & 11.8 & 13.5 & 40.1 & 23.3 & 9.8 \\
\hline 48 & 28.8 & 15.9 & 21.2 & 8.8 & 25.8 & 13.4 & 20.6 & 8.3 \\
\hline 72 & 28.7 & 16.3 & 20.9 & 8.3 & 25.9 & 16.6 & 20.3 & 8.0 \\
\hline 96 & 25.5 & 17.3 & 16.2 & 7.8 & 22.9 & 21.6 & 15.2 & 7.8 \\
\hline 120 & 25.4 & 24.3 & 14.0 & 7.8 & 21.6 & 35.1 & 11.5 & 7.3 \\
\hline
\end{tabular}

a) The cells were grown in a medium containing $2 \%$ starch, $2 \%$ maltose, $1 \% \mathrm{NaNO}_{3}$ and $0.01 \% \mathrm{CaCO}_{3}$ in $3 \%$ soybean meal extract $(\mathrm{pH} 7.0)$ at $28^{\circ} \mathrm{C}$ with shaking. 
$24 \mathrm{hr}$ growth, but decreased and fell to a minimum at $48 \mathrm{hr}$. The content in idiophase then increased gradually and was restored to near the initial level. On the other hand, as shown in Table $\mathrm{X}$, the level of isocitrate lyase

\section{Table $X$. Change in the Level of Isocitrate Lyase dURING KM FERMENTATION With OR WITHOUT ADDITION OF SCL}

\begin{tabular}{ccc}
\hline \multirow{2}{*}{\begin{tabular}{c} 
Age $^{a} \begin{array}{c}\text { of cells } \\
\text { hr }\end{array}$ \\
\cline { 2 - 3 }
\end{tabular}} & \multicolumn{2}{c}{ Activity $^{b)}$} \\
\hline 24 & No addition & SCL (5 ppm) \\
48 & 2.43 & 2.16 \\
72 & 1.53 & 0.88 \\
96 & 0.81 & 1.30 \\
120 & 1.12 & 1.33 \\
\hline
\end{tabular}

a) The same as in Table IX.

b) u/100 mg dry cells/10 min.

during KM frementation changed in accordance with the carbohydrate content of cells.

\section{DISCUSSION}

As shown in the present experiments, the formation of NAKA in $S$. kanamyceticus is associated with a gluconeogenetic metabolism via glyoxylate bypass, the key enzyme of which is isocitrate lyase. NAKA provides acetate to the glyoxylate cycle and NAK serves as the acetate pool in the cells. It is of significance that the endogenous activity of NAKA in the washed-cell suspensions is induced by acetate along with the activity of isocitrate lyase and $\mathrm{N}$-acetyltyrosine amidohydrolase. Acetate first stimulates the enzymes of glyoxylate cycle, depressing the level of isocitrate, and the loss of isocitrate or citrate in the cells may in turn induce the activity of NAKA. N-Acetyltyrosine represses the activity of NAKA in washed cells having the activity of $\mathrm{N}$-acetyltyrosine amidohydrolase. This may be due to the inhibition of the reductive process of gluconeogenesis by some degrative reaction of tyrosine which requires NADPH.

SCL stimulates the activity of isocitrate lyase per se and increases the carbohydrate synthesis in cells in early trophophase and in the latter half of idiophase, as described above. The effect of SCL may involve the formation of acetyl $\sim \mathrm{CoA}$ through the activity of citrate lyase, acetate kinase and phosphotransacetylase, as reported previously. ${ }^{13}$ On the other hand, the carbon source has a relationship to the regulation of NAKA, where the adenylate energy charge may be significant, because cyclic AMP releases the repression of NAKA by glucose. Since SCL has a stimulating effect on amino acid incorporation into the protein fraction of plant and animal tissues, the reverse effect by the combination of SCL and some amino acids, such as aspartic and glutamic acids, on catabolite repression of NAKA may result from the compensation of the adenylate energy consumed for protein synthesis. The change in chemical composition of cells during $\mathrm{KM}$ fermentation may involve a structural change in the cells. The effect of toluol-treatment on the endogenous activity of NAKA appears to have a profound relationship to the structure of the cell wall or cell membrane.

\section{REFERENCES}

1) A. Satoh, H. Ogawa and Y. Satomura, Agr. Biol. Chem., 39, 2331 (1975).

2) D. E. Atkinson, Ann. Rev. Microbiol., 23, 47 (1969).

3) J. L. Canovas and H. L. Kornberg, Biochem. Biophys. Res. Commun., 22(2), 194 (1966).

4) B. D. Sanwal and P. Maeba, Biochim. Biophys. Acta, 96(1), 169 (1965).

5) A. Satoh, H. Ogawa and Y. Satomura, Agr. Biol. Chem., 39, 1593 (1975).

6) H. Hatano and A. Etoh, Kagaku no Ryôiki, 33, 56 (1959).

7) H. H. Daron and I. C. Ganalus, "Methods in Enzymology," Vol. V, Academic Press, Inc., New York, 1962, p. 628.

8) G. Schmidt and S. J. Thanhauzer, J. Biol., 161, 83 (1945).

9) W. C. Schneider, J. Biol. Chem., 161, 293 (1945).

10) W. C. Schneider, ibid., 169, 747 (1946).

11) K. Nishizawa, "Seikagaku Kenkyu Ho I," Asakura Sho-ten Co., Tokyo, Japan, 1967, p. 181.

12) "Methods in Carbohydrate Chemistry," Vol. 5, ed. by R. L. Whistler, Academic Press, Inc., New York, 1965, p. 3 (A. O. Pittet), p. 80 (W. T. 
J. Morgan), p. 83 (O. Westphal and K. Jann), p. 93 (A. M. Stanb).

13) M. Dubois, K. A. Gilles, J. K. Hamilton, P. A. Rebers and F. Smith, Anal. Chem., 28, 350 (1956).

14) L. A. Elson and W. T. L. Morgan, Biochem. J.,
27, 1824 (1933).

15) A. Steyermark, "Quantitative Organic Microanalysis," 2nd ed., Academic Press, Inc., New York, 1961. 